\title{
Antimicrobial Hydrogels Based on 2-hydroxyethyl Methacrylate and Itaconic Acid Containing Silver(I) Ion
}

\author{
NEDA B. MALEŠIĆ, University of Belgrade, \\ Faculty of Technology and Metallurgy, Belgrade
A D. RUSMIROVIC, University of Belgrade, \\ JELENA D. RUSMIROVIĆ, University of Belgrade,
Faculty of Technology and Metallurgy, Belgrade \\ JOVANA S. JOVA ̌́EVIĆ, University of Belgrade, \\ Faculty of Technology and Metallurgy, Belgrade \\ MARIJA D. PERIŠIĆ, University of Belgrade, \\ Faculty of Technology and Metallurgy, Belgrade \\ SUZANA I. DIMITRIJEVIĆ, University of Belgrade, \\ Faculty of Technology and Metallurgy, Belgrade \\ JOVANKA M. FILIPOVIĆ, University of Belgrade, \\ Faculty of Technology and Metallurgy, Belgrade \\ SIMONIDA LJ. TOMIĆ, University of Belgrade, \\ Faculty of Technology and Metallurgy, Belgrade
}

Original scientific paper UDC: 615.46:678.71.

\begin{abstract}
The objective of our study was to develop new antimicrobial hydrogels silver/poly(2-hydroxyethyl methacrylate/itaconic acid) (Ag/P(HEMA/IA)). The P(HEMA/IA) samples, with different HEMA/IA ratio, were prepared by free radical crosslinking copolymerization. Ag ion were introduced in hydrogels by immersing dried P(HEMA/IA) disks in silver(I) salt solution, which was confirmed by FTIR spectroscopy. The in vitro controlled release of silver(I) ion from (Ag/P(HEMA/IA)) gels, and antimicrobial activity during the release period were also studied. The release profiles have shown a two-phase exponential profile, with fast initial phase, followed by a much slower release rate. Kinetic parameters determined, have indicated Fickian transport of $\mathrm{Ag}(I)$ ion in the initial phase. It is perceived that the antimicrobial activity of the $\mathrm{Ag} / \mathrm{P}(\mathrm{HEMA} / \mathrm{IA})$ depends on IA content. Excellent antimicrobial potential was maintained during the entire release time. The
\end{abstract}

Key words: 2-Hydroxyethyl methacrylate, Itaconic acid, Hydrogel, Silver(I) ion, Controlled release, Antimicrobial potential

\section{INTRODUCTION}

The polymers with antimicrobial properties are required in many areas but they are particularly desirable in health care, hygiene and food packaging. Antibiotics and biocides can be used to develop antimicrobial polymer but they are toxic to human health and ecosystem [1].

Author's address: Neda Malešević, University of Belgrade, Faculty of Technology and Metallurgy, Belgrade, Karnegijeva 4

Paper received: 21.05.2014.

Paper accepted: 05.06.2014.
Since the emergence of multidrug resistant micro organisms and ever increasing trend of health care cost, researchers are trying to introduce new antimicrobials agents which are effective against drug resistant bacteria, economically cheaper and which can be easily incorporated into polymers having wide range of application [2].

Generally, the use of conventional antimicrobial agents is associated with the problems of residual toxicity of these agents which can cause more serious problems to the environment. Due to the associated problems result from the use of conventional antimicrobial agents; the idea of polymeric antimicrobial 
agents appeared to be an attractive alternative. Nowadays, there is an increasing interest in selective antimicrobial polymers whose potency against bacteria and non-toxicity towards mammalian cells distinguishes them from most polymeric biocides that are broadly poisonous $[3,4]$. In addition, the use of polymeric antimicrobial agents have the advantages that they are nonvolatile, chemically stable, and find it difficult to permeate through the skin of man or animal and may enhance the efficacy of some existing antimicrobial agents and minimize the environmental problems accompanying the residual toxicity of the agents in addition to prolonging their lifetime [3, 4]. Therefore, the use of polymeric materials with antimicrobial properties gains an increasing interest from both academic and industrial point of view.

Among the different antimicrobial agents investigated so far silver ion are considered the most promising antimicrobials agent active against wide range of microorganisms and non toxic to cells [5 - 7]. Recently due to its unique physiochemical and medicinal properties there is renaissance in exploring its antimicrobial potential. Mechanism of action of silver on microorganisms is still unclear.

However according to structural and morphological changes in bacterial cells possible mechanism has been suggested. The effect of silver ion on bacteria can be observed by the changes resulting by the reaction of silver ion with cell components. When the silver ion enter the cell the DNA loses the ability to replicate silver ion also deactivate proteins by reacting with thiol group.

Hydrogels are hydrophilic homo- or copolymer systems consisting of three-dimensional networks. Because they have the possibility of absorbing large amounts of water and biological fluids, they are biocompatible, and therefore, they are often used in biomedicine and biotechnology [8 - 12].

Polymeric hydrogels can act as matrix for the materials holding the antimicrobial agents [13]. 2Hydroxyethyl methacrylate (HEMA) was chosen as the main component of the hydrogel network because this functional monomer and its copolymers exhibit excellent biocompatibility, blood compatibility, cytotoxicity, cell compatibility and low thrombogenicity [14]. It is a commercially important monomer that is widely used in the manufacture of soft contact lenses and intraocular lenses $[15,16]$. Itaconic acid (IA) is very hydrophilic and is expected to show high biocompatibility because of its natural source.

IA easily copolymerizes and provides polymer chains with carboxylic side groups, with different $\mathrm{pKa}$ values $\left(\mathrm{pK}_{\mathrm{a} 1}=3.85\right.$ and $\left.\mathrm{pK}_{\mathrm{a} 2}=5.45\right)$, which are highly hydrophilic and able to form hydrogen bonds with corresponding groups. Small amounts of itaconic acid comonomer in the gel network introduce $\mathrm{pH}$ sensitivity and increase the degree of swelling. In addition, incorporation of such comonomers, able to form H-bonds, can increase the mechanical strength of the hydrogel [17]. Hydrogels have the available carboxylic acid functional groups, which can be used in any further incorporation of drugs or other bioactive agents $[16,17]$. It has been pointed out that polymers or copolymers containing carboxylic acid groups (such is itaconic acid) are highly desirable in biomaterials, as such groups represent functionality useful for yielding a wide variety of biomedical products [17].

In our work we report the results obtained for hydrogels based on 2-hydroxyethyl methacrylate and itaconic acid with silver(I) ion, designed as new antimicrobial polymeric biomaterials. Ag/P(HEMA/IA) samples were characterized for their structural characteristics, controlled release properties, as well as for their antimicrobial performances.

\section{MATERIALS AND METHODS}

\section{Materials}

2-Hydroxyethyl methacrylate (HEMA, Aldrich), freshly distilled, itaconic acid (IA, Fluka), were the monomers used in this study. Ethylene glycol dimethacrylate (EGDMA, Aldrich), as crosslinking agent, potassium persulfate (KPS, Fluka), as initiator, and N, $\mathrm{N}, \mathrm{N}^{\prime}, \mathrm{N}^{\prime}$-tetramethylethylene diamine (TEMED, Aldrich), as activator, were used in all polymerization performed in a mixture of water/ethanol solution. Potassium hydrogen phosphates $\left(\mathrm{KH}_{2} \mathrm{PO}_{4}\right.$ and $\mathrm{K}_{2} \mathrm{HPO}_{4}$, $\mathrm{La}$ Chema) were used for buffer preparation. Source of silver(I) ion is silver nitrate salt (Fluka). Demineralized water was used for all copolymerization and the preparation of the buffer solution.

\section{Preparation of hydrogels}

P(HEMA/IA) copolymeric hydrogels were prepared by free radical crosslinking copolymerization, with IA mole fraction of 0.0, 2.0, 3.5, and 5.0. Initiator, activator and crosslinker were added to the monomer feed, previously dissolved in water/ethanol mixture, which was than purged with nitrogen and placed between two glass plates sealed with a rubber spacer $(2$ $\mathrm{mm}$ thick). The polymerization was carried out at $50^{\circ} \mathrm{C}$ for $24 \mathrm{~h}$. After the reaction, the gels were cut into discs and immersed in water for a week, to remove unreacted components.

The water was changed daily. The discs were dried to obtain xerogels. The unreacted monomers were determined using a UV spectroscopy and by titration of extract against $\mathrm{NaOH}(0.05 \mathrm{~mol} / \mathrm{l})$ to phenolphthalein end-point, respectively. The results indicate that the conversion during crosslinking copolymerization was 
nearly complete. According to the varying IA mole fraction the samples were designated as PHEMA, P(HEMA/2IA), P(HEMA/3.5IA), and P(HEMA/5IA), respectively. In order to incorporate of silver(I) ion in hydrogel, the polymer disks are soaked in $\mathrm{AgNO}_{3}$ solution $\left(\mathrm{c}=10^{-3} \mathrm{M}\right)$, in the absence of light, for two days. Thus, swollen gels with the active agent were dried at room temperature to a constant weight, and still used in controlled release experiments.

\section{FTIR spectroscopy}

Dry gels were crushed into a powder and mixed with potassium bromide (Merck IR spectroscopy grade) in the proportion 1:100, and dried at $40 \mathrm{oC}$. The mixture was compressed to a $12 \mathrm{~mm}$ semi-transparent disk by applying a pressure of $65 \mathrm{kN}$ (Pressure gauge, Shimadzu) for $2 \mathrm{~min}$. FTIR spectra over the wavelength range 4000-700 $\mathrm{cm}-1$, with a resolution of $4 \mathrm{~cm}-$ 1, were recorded using a FTIR spectrometer (BOMEM Michelfan MB-102 FTIR).

\section{Controlled release study}

For the investigation of the therapeutic agent release behavior of P(HEMA/IA) hydrogels prepared in this study, silver(I) ion was used as active agent. Xerogel discs, swollen in silver(I) solution $\left(c=1 \times 10^{-3}\right.$ M) to equilibrium, were dried at ambient temperature for several days to constant mass. The release studies have been carried out in vitro by placing dry agent loaded sample in $10 \mathrm{ml}$ of $\mathrm{pH} 7.40$ buffer solution at $37^{\circ} \mathrm{C}$, which was stirred constantly.

Sink condition were provided throughout the experiments. The release of the drug was monitored by withdrawing $2.0 \mathrm{ml}$ aliquots from the dissolution medium at predetermined time points, filtered, properly diluted and assayed for silver(I) ion, using an atomic absorption spectrophotometer (Varian Model AA-12), and finally returned to the bulk solution. All release experiments were performed in triplicate.

\section{Antimicrobial activity assay}

The antimicrobial assay was done against gramnegative Escherichia coli (ATCC 25922) bacteria. The hydrogel samples were inoculated in tubes with saline solution. The number of bacterial cells was c.a. $10^{4} \mathrm{ml}^{-}$ ${ }^{1}$ for strains. The tests were performed in three replicas and the results calculated as a mean value. The tubes were placed into a shaker $(120 \mathrm{rpm})$ in a thermostated water bath at $37{ }^{\circ} \mathrm{C}$, to assure the better contact of tested hydrogels and bacterial cells.

For this purpose, the sterile Petri plates were inoculated with an aliquot $(100 \mu \mathrm{l})$ of saline solution with tested hydrogels and bacterial cultures and overlaid with melted TSA. After solidification of agar and the incubation at $37^{\circ} \mathrm{C}$ for $24 \mathrm{~h}$, the counting of visible colony was performed. Inhibition of microbial growth (\%) was calculated as the ratio of visible colony number for each sample and that for the control.

\section{RESULTS AND DISCUSSION}

The formation of poly(2-hydroxyethyl methacrylate/itaconic acid) hydrogels ((Ag/P(HEMA/IA ) ) containing silver(I) ion is presented in Scheme 1.

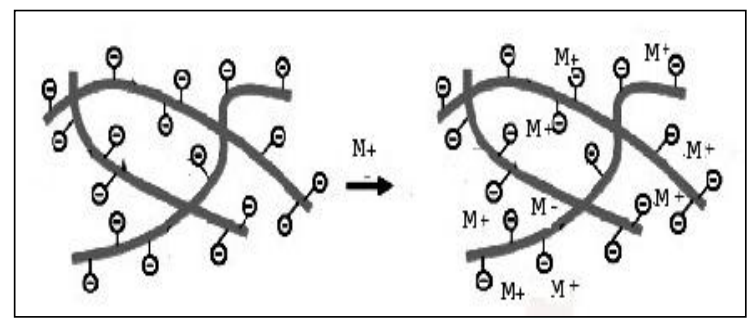

Scheme 1 - Formation of P(HEMA/IA) hydrogel network containing (silver(I)) ion.

\section{FTIR spectra}

In order to characterize the obtained hydrogel, we have recorded the FTIR spectra of the hydrogels. The FTIR spectra of P(HEMA/IA) and Ag/P(HEMA/IA) are shown in Fig. 1. The main peaks characteristic for HEMA and IA components are the $\mathrm{C}=\mathrm{O}$ group at 1730 $\mathrm{cm}^{-1}$ and $1645 \mathrm{~cm}-1$, and $\mathrm{O}-\mathrm{H}$ stretching at $3440 \mathrm{~cm}^{-}$ ${ }^{1}$. The band at $2900 \mathrm{~cm}-1$ corresponds to the stretching vibration of the aliphatic $\mathrm{CH}_{2}$. The $\mathrm{Ag} / \mathrm{P}(\mathrm{HEMA} / \mathrm{IA})$ (Figure 1(black line)) has shown all the above characteristic peaks with a slight shift to higher wavelengths. This shifting can be attributed to the formation of bonds between the silver and the electron rich groups (such as $\mathrm{C}=\mathrm{O}$ and $\mathrm{OH}$ ) present in the hydrogel network. Other characteristic bands represent $\mathrm{C}-\mathrm{C}$ and $\mathrm{C}-\mathrm{H}$ vibration of $-\mathrm{CH}_{3}$ and $-\mathrm{CH}_{2}$ groups [18].

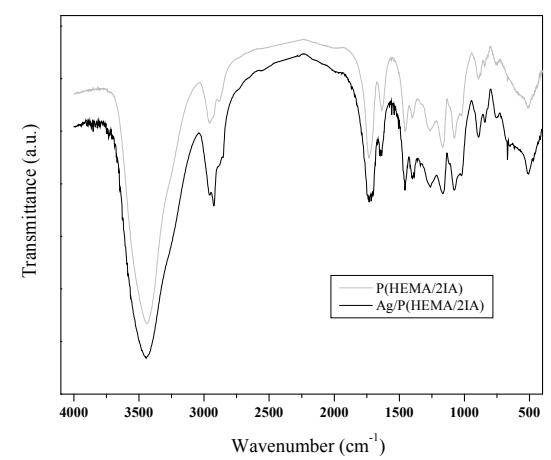

Figure 1 - FTIR spectra of $P(H E M A / I A)$ and $A g / P$ (HEMA/IA) samples.

\section{Controlled release study}

The release of the active agents of the hydrogel depends on the characteristics of the polymer network, such as the chemical structure of the polymer, the network structure, and the condition in which the release is performed. On the other hand, the physico-chemical properties of the active agent also have some influence. The therapeutic agent in our study was silver(I) ion. 
The kinetics of release was analysed by using equation (1):

$$
\frac{M_{t}}{M_{e}}=k t^{n}
$$

where $M_{t} / M_{e}$ is the fractional ion release, $t$ is the release time, $n$ is diffusional exponent, and $k$ is kinetic constant. The in vitro release profiles of silver(I) ion from $\mathrm{Ag} / \mathrm{P}(\mathrm{HEMA} / \mathrm{IA})$ hydrogels (buffer of $\mathrm{pH} 7.40$, at $37^{\circ} \mathrm{C}$ ) are shown in Figure 2. In the first phase, release of silver(I) ion was fast. It could be explained by ion adsorbtion on the surface of the hydrogel samples and the appearance of the "burst" effect (Figure 2). Looking at the fractional ion release in the first (initial) phase (first day), it can be seen that most of the silver ion was released from $\mathrm{Ag} / \mathrm{P}(\mathrm{HEMA} / 5 \mathrm{IK})$ $\left(M_{t} / M_{e}=0.875\right)$, followed by Ag/P(HEMA/3.5IK) $\left(M_{t} / M_{e}=0.711\right)$ and Ag/P(HEMA/2IA $)\left(M_{t} / M_{e}=0.612\right)$, while the lowest concentration of silver ion was released from the Ag/PHEMA $\left(M_{t} / M_{e}=0.585\right)$ hydrogels. This trend in the release of silver ion from P(HEMA/IA) hydrogel samples is set by IA content; for higher IA content the number of $\mathrm{COOH}$ groups that can bind silver ion increases. Hence, the ratio $M_{t} / M_{e}$ increases with increasing IA content, during in vitro release silver ion. In the II phase $\left(2^{\text {nd }}-4^{\text {th }}\right.$ day) of release all hydrogels showed reduced concentration of released $\mathrm{Ag}$ ion, but a similar trend as compared to the proportion of IA in the hydrogel, followed by the establishment of the steady state. From Fig. 2 it can be concluded that the lowest fractional ion release was from the Ag/PHEMA hydrogel. It is important to note that the concentration of silver ion released from $\mathrm{Ag} / \mathrm{P}(\mathrm{HEMA} / \mathrm{IA})$ hydrogels was in the therapeutic range, within the release period of 7 days.

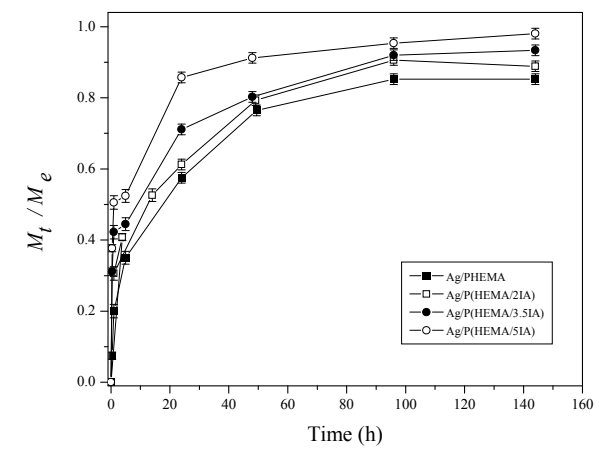

Figure 2 - Silver(I) ion release profiles of $P$ (HEMA/IA) hydrogels.

Values of release exponent ( $n$ ) for Ag/PHEMA and Ag/P(HEMA/IA) hydrogels are shown in Table 1. Diffusion coefficients were calculated using equation (2):

$$
\frac{M_{t}}{M_{e}}=4\left(\frac{D t}{\pi l^{2}}\right)^{1 / 2}
$$

where $D$ is the diffusion coefficient of the therapeutic agent that is released from the gel, $t$ is the time, and $l$ is the sample thickness. The values of the diffusion coefficients of the silver ion $(D)$, are also presented in Table 1 . The values of the diffusion coefficients for hydrogels also depend on the composition and are in the range of $0.25-4.05 \times 10^{-7} \mathrm{~cm}^{2} / \mathrm{s}$.

Table 1. Release kinetics parameters of $\mathrm{Ag} / \mathrm{P}(\mathrm{HEMA} / \mathrm{IA})$ hydrogels

\begin{tabular}{|l|l|l|l|}
\hline Sample & $\begin{array}{l}k \\
\left(h^{-n}\right)\end{array}$ & $n$ & $\begin{array}{l}D \times 10^{7} \\
\left(\mathrm{~cm}^{2} / \mathrm{s}\right)\end{array}$ \\
\hline Ag/PHEMA & 0.148 & 0.467 & 0.25 \\
\hline Ag/P(HEMA/2IA $)$ & 0.378 & 0.181 & 1.64 \\
\hline Ag/P(HEMA/3.5IA $)$ & 0.417 & 0.128 & 2.13 \\
\hline Ag/P(HEMA/5IA $)$ & 0.615 & 0.056 & 4.05 \\
\hline
\end{tabular}

Antimicrobial assay

Antimicrobial activity is a very valuable property for biomedical application of hydrogels [19 - 22] because bacterial infection from medical devices is a major problem and accounts for an increasing number of deaths as well as high medical costs. Hydrogel implants and other medical devices having good antimicrobial properties are protected from infection during their use. A study of antimicrobial activity of Ag/P(HEMA/IA) hydrogels was made to determine their efficacy towards E. coli pathogens. According to the results obtained (Figure 3 ) it is evident that the antimicrobial activity is excellent for all samples, and to a small extent depends on the release time and IA content. Generally, hydrogels containing higher IA content showed better antimicrobial activity. Regarding the influence of the release time, all samples show slightly increase of antimicrobial activity for time. The best sensitivity was obtained for the samples with $5 \mathrm{~mol} \%$ of IA. It was confirmed excellent efficacy of silver ion, which were released in a controlled manner from P(HEMA/IA) hydrogels in vitro, against to $E$. coli bacteria.

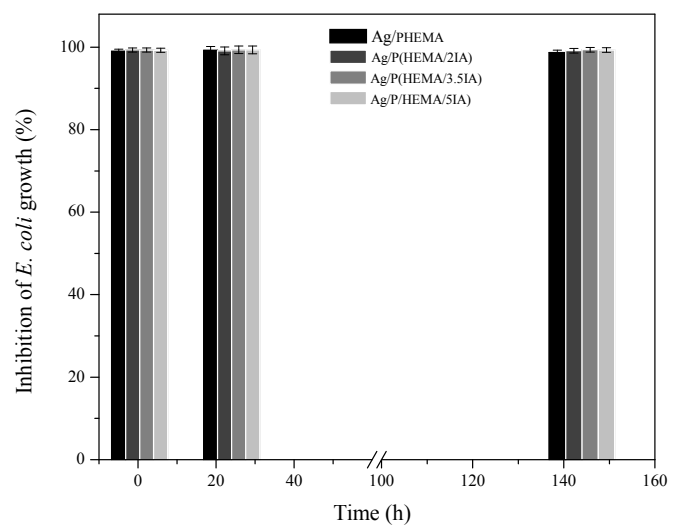

Figure 3 - The antimicrobial activity of $\mathrm{Ag} / \mathrm{P}(\mathrm{HE}$ $M A / I A)$ hydrogels against E. coli, at certain intervals during the in vitro controlled release. 


\section{CONCLUSION}

In our study, new antimicroabial hydrogels were prepared by free radical crosslinking/ copolymerization of 2-hydroxyethyl methacrylate and itaconic acid, with silver(I) ion introduced by immersing dried $\mathrm{P}(\mathrm{HEMA} / \mathrm{IA})$ disks in silver(I) salt solution (Ag/P(HEMA/IA)). FTIR spectroscopy measurements confirmed the chemical structure of obtained hydrogels. The release profiles have shown a two-phase exponential pattern, with fast initial phase, followed by a much slower release rate. Kinetic parameters determined as well as release profiles indicate the strong dependence on the itaconic acid content in the samples. It is perceived that the antimicrobial activity of the Ag/P(HEMA/IA) was excellent against $E$. coli bacterial strains, and to a small extent depends on the release time and IA content. The obtained results for Ag/P(HEMA/IA) hydrogels show satisfied potential as polymeric matrices for biomedical application. Their versatility to be designed with specifically tuned release properties renders these biomaterials promising pharmaceutical carriers for therapeutic agents.

\section{ACKNOWLEDGMENTS}

This work has been supported by the Ministry for education, science and technological development of the Republic of Serbia (Grants No 172026 and 172062).

\section{REFERENCES}

[1] Stara H., Stary Z. K., Munstedt H., Macromol. Mater. Eng., 5, 296, p. 423-427, 2011.

[2] Kim J. S., Kuk E., Yu K. Y., Kim J. H., Park Y. K., Park Y. H., Hwang C. Y., Kim Y. K., Lee Y. S., Jeong D. H., Cho M. H., Nanomed. Nanotechnol., 1, 3, p. 95-101, 2007.

[3] Kenawy E-R., Worley SD., Broughton R., Biomacromolecules, 5, 8, p. 1359-1384, 2007.

[4] Klibanov A. M., J. Mater. Chem., 24, 17, p. 24792482, 2007.

[5] Kong H., Jang J., Langmuir, 5, 24, p. 2051-2056, 2008.

[6] Jovašević J. S., Mićić M. M., Suljovrujić E. H., Filipović J. M., Dimitrijević S.I., Tomić S. Lj., Hem. Ind., 3, 64, p. 209-214, 2010.
[7] Mićić M. M., Tomić S. Lj., Filipović J. M., Suljovrujić E. H., Hem. Ind., 3, 63, p. 137-142, 2009.

[8] Ratner, B. D., Hoffman, A. S., Schoen, F. J., Lemons, J. E., Biomaterials Science: An introduction to materials in medicine, Elsevier Academic Press, Boston, 2004.

[9] Kopecek J., Yang J., Polym. Int., 9, 56, p. 1078-1098, 2007.

[10] Slaughter B. V., Khurshid S. S., Fisher O. Z., Khademhosseini A., Peppas N. A., Adv. Mater., 32-33, 21, p. 3307-3329, 2009.

[11] Sheena A., Sean B., Kazuhiko I., Anthony G.- E., Biomaterials, 23, 26, p. 4767-4778, 2005.

[12]Peppas N. A., Hilt J.Z., Khademhosseini A., Langer R., Adv. Mater., 11, 18, p. 1345-1360, 2006.

[13] Munoz-Bonilla A., Fernandez-Garcia M., Prog. Polym. Sci., 2, 37, p. 281-339, 2012.

[14]Prasitsilp M., Siriwittayakorn T., Molloy R., Suebsanit N., Siriwittayakorn P., Veeranondha S., J. Mater. Sci., 7, 14, p. 595-600, 2003.

[15]Barrett G. D., Constable I. J., Stewart A. D., J. Cataract Refr. Surg., 6, 12, p. 623-631, 1986.

[16] Menapace R., Skorpik C., Juchem M., Scheidel W., Schranz R., J. Cataract Refr. Surg., 3, 15, p. 264-271, 1989.

[17] Tomić S. Lj., Suljovrujić E. H., Filipović J. M., Polym. Bull., 5, 57, p. 691-702, 2006.

[18] Silverstein R. M., Bassler G. C., Morrill J. C., Spectrometric identification of organic compounds, John Wiley and Sons Inc, New York, 1991.

[19]Yu H., Xu X., Chen X., Lu T., Zhang P., Jing X., J. Appl. Polym. Sci., 1, 103, p. 125-133, 2007.

[20] Sawan S. P., Manivannan G., Antimicrobial/anti-infective materials: principles and applications, CRC Press, USA, 1999.

[21] Martineau L., Shek P. N., Burns, 2, 32, p.172-179, 2006.

[22] Houghton P. J., Hylands P. J., Mensah A. Y., Hensel A., Deters A.M., J. Ethnopharmacol., 1-2, 100, p.100-107, 2005. 


\section{REZIME}

\section{ANTIMIKROBNI HIDROGELOVI NA BAZI 2-HIDROKSIETIL METAKRILATA I ITAKONSKE KISELINE KOJI SADRŽE SREBRO(I) JON}

Cilj našeg istraživanja je bio da se razviju novi antimikrobni hidrogelovi. Srebro/poli(2-hidroksietil metakrilat/itakonska kiselina) (Ag/P(HEMA/IK)) hidrogelovi su sintetisani, i proučavano je kontrolisano otpuštanje srebro(I) jona iz Ag/P(HEMA/IK) hidrogelova, kao i njihov antimikrobni potencijal. P(HEMA/IK) uzorci, sa različitim odnosima monomera HEMA/IK, dobijeni su radikalnom kopolimerizacijom/umrežavanjem. Ag/P(HEMA/IK) hidrogelovi su formirani potapanjem suvih diskova gelova u srebro(I) so, što je i potvrđeno FTIR spektroskopijom. Ispitani su kontrolisano otpuštanje srebro(I) jona iz Ag/P(HEMA/IA) gelova in vitro, kao i antimikrobna aktivnost tokom perioda otpuštanja. Profili otpuštanja su pokazali dve faze (eksponencijalni rast), sa brzom početnom fazom, a zatim sporijom brzinom otpuštanja. Antimikrobna aktivnost u toku otpuštanja u maloj meri zavisi od sadržaja IA i vremena otpuštanja. Odličan antimikrobni potencijal se održava tokom celog vremena otpuštanja. Na osnovu dobijenih rezultata proizilazi da se Ag/P(HEMA/IK) hidrogelovi mogu koristiti u širokom spektru biomedicinskih primena.

Ključne reči: 2-Hidroksietil metakrilat, itakonska kiselina, hidrogel, srebro(I) jon, kontrolisano otpuštanje, antimikrobni potencijal 